\title{
Screening for Identification of Resistance Sources of Tomato against Tomato Leaf Curl Virus (ToLCV) from Segregating Population and Private Sector Hybrids under Natural Disease Incidence
}

\author{
Raghavendra Achari $^{*}$, B. Fakruddin ${ }^{2}$, K.T. Rangaswamy ${ }^{3}$, D.L. Savithramma ${ }^{4}$, \\ Kedarnath $^{5}$, N. Nagaraju ${ }^{3}$ and H.A. Prameela ${ }^{6}$ \\ ${ }^{1}$ Department of Plant Pathology, UHS, Bagalkot, India \\ ${ }^{2}$ Department of Biotechnology and Crop Improvement, UHS, Bagalkot, India \\ ${ }^{3}$ Department of Plant Pathology, UAS, Bengaluru-560065, India \\ ${ }^{4}$ Department of Genetics and Plant Breeding, UAS, Bengaluru-560065, India \\ ${ }^{5}$ Department of Plant Protection, ICAR-KVK (DK), Mangalore-575002, India \\ ${ }^{6}$ Department of Plant Pathology, UAS, Bengaluru-560065, India \\ *Corresponding author
}

\section{A B S T R A C T}

Tomato leaf curl virus (ToLCV) is one of the most serious plant viral pathogen of tomatoes grown in tropical and subtropical regions of the world. The virus is a monopartite and bipartite Gemini virus, transmitted by the tobacco whitefly, Bemisia tabaci (Gennadius). In an effort to identify the resistance source/s against this disease, 47 tomato segregating population from F1 generation from the cross between resistant parents (DMT2 X COHBT24) and 37 private sector commercial tomato hybrids were screened for resistance against ToLCV during summer season (2017) under natural disease incidence condition. Tomato seedlings grown on portrays ( 28 days old) were transplanted on to the main field. The observations on per cent incidence (PI), per cent disease index (PDI) were recorded at 30 days interval after transplanting (60 and 90 DAS) and Area under Disease Progress Curve (AUPDC) values were calculated. Among the population screened, no visual symptoms of ToLCV infection were observed in COHBTTF1/11-4, whereas maximum ToLCVD severity (45 PDI) was recorded in COHBTTF1/325-1 even at 90 days after transplanting (DAT). The entire population evaluated was grouped into resistant (11 Nos.), mild infection (38 Nos.) and moderate infection (35 Nos.) exclusively based on resistance reaction against ToLCV. The AUDPC values for ToLCVD ranged from 0 (COHBTTF1/11-4) to 1275 (COHBTTF1/325-1). For categorization of the tomato genotypes/hybrids into different resistance reaction groups, the AUDPC values depicting the resistance reaction over the entire period of study need to be considered in addition to PI and PDI values at a standard time of observation.

\section{Introduction}

Tomato (Solanum lycopersicum L.) belongs to Solanaceae family is an important vegetable crop mainly cultivated for its edible fruits. Tomato is reported to be cultivated in wide climatic conditions covering both tropical and subtropical countries of the world. Tomatoes preferred for their taste, apart from equally important as source of vitamin 'A', vitamin 'B1', vitamin 'B3', nicotinic acid, vitamin ' $\mathrm{C}$ ', vitamin ' $\mathrm{K}$ ', lycopene, phosphorus and 
potassium. Ripened tomato fruits provide approximately $18 \mathrm{kcal}$ of energy per $100 \mathrm{~g}$ of raw fruit. Tomato fruits gained importance during recent past for its medicinal, antioxidant property and processing potential. Ability of tomato crop to adapt to different climatic and growing conditions viz., open field, greenhouses and net-houses cultivation has increased the significance of tomato cultivation. India occupies second position next to China in global tomato production.

In India, tomato cultivation occupied in an area of about 7,74,000 hectares and contributing an annual production of 18.73 million tonne with a productivity of 20.70 tonne per hectare. Madhya Pradesh, Andhra Pradesh, Karnataka, Telangana, Gujarat, Odisha, West Bengal, Bihar and Maharashtra are the major tomato growing states in the country (Anon., 2017). In Karnataka, tomato being cultivated in an area of 65,545 hectares with an annual production of 2.06 million tonne and productivity of 31.37 tonne per hectare (Anon., 2013). Bengaluru, Belagavi, Tumakuru, Chikkaballapura, Kolar, Hassan, Haveri and Davanagere are the major tomato cultivating districts in Karnataka.

Several fungal, bacterial, phytoplasma, nematode and virus diseases known to infect tomato crop and among the viral diseases infecting tomato, tomato leaf curl virus disease (ToLCVD) caused by Tomato leaf curl virus (ToLCV) (family Geminiviridae, genus Begomovirus) is the most destructive disease in major tomato growing regions of India (Saikia and Muniyappa, 1989) and the world. The ToLCV is known to be transmitted by whitefly vector, Bemisia tabaci (Gennadius) (Hemiptera: Aleyrodidae) in persistent and circulative manner. The genus Begomo virus has more than 192 recognized species (Brown et al., 2011) and most of them are transmitted by B. tabaci alone (Brown, 2010). In Karnataka, the ToLCVD incidence ranged from 17-100 per cent in different tomato growing areas across the seasons depending on the stage of the infection.

The major component of Integrated Disease Management (IDM) is exploration of available host plant resistance by proper identification resistance source is the most economical and a potential approach for plant disease management as it is safe to environment in comparison with use of chemical pesticides. Efforts for exploring hybrid vigour to develop resistant varieties are a continuous effort both in public and private sector institutes. Open pollinated tomato varieties like Nandi, Sankranti and Vybhav with specific resistance against ToLCV infection from UAS, Bengaluru, and Arka Rakshak, a triple resistant hybrid from ICAR-IIHR, Bengaluru have been made available for cultivation. On the other side, simultaneously evolving variability among the ToLCV strains and its whitefly vector, $B$. tabaci are posing serious challenge for the management and breaking down of field resistance of the varieties or hybrids under cultivation. The durability of resistance against ToLCV is a serious concern which further necessitates continuous search for resistance source either within the available variability or by creating variability and / or development of resistance sources.

The efforts for identification of resistance sources both within the species and also across related species of the genus, Solanum, and using the identified resistance sources in further breeding programmes for development of resistant hybrids or variety was started during long back. The evaluation of germplasm and hybrids for their reaction against ToLCV was performed based on the visual symptoms of ToLCVD either by observing under field conditions or after artificial inoculation of virus using viruliferous whitefly vector. The variety Pusa Ruby was breed and cultivars like Hissar 
Anmol and Hissar Gaurav were identified with relatively less susceptible to whiteflies and in turn less susceptible to ToLCV infection under Madhya Pradesh condition.

Similarly, by conventional breeding and screening methods using viruliferous whitefly vector, three fresh market tomato lines viz., TLB111, TLB130 and TLB182 (Sankranthi, Nandi and Vybhav) were developed from UAS Bengaluru in collaboration with then AVRDC Taiwan and Natural Resource Institute (NeRI), United Kingdom which are resistant to south Indian and Taiwan geminiviruses, and tolerant to bacterial wilt (Muniyappa et al., 2002). They have been used in further breeding programmes as sources of resistance to develop tomato hybrids. Further, in an effort to develop varieties / lines having virus strain specific resistance i.e. ToLCV-[Ban4] strain was performed. In the present article, we report the screening results of tomato germplasm and private sector hybrids for field resistance to the ToLCV. The plants were assayed according to visual symptoms of the leaf curl disease under field infection condition.

\section{Materials and Methods}

The tomato segregating population from $F_{1}$ generation (47 Nos.) which were developed by crosses between parent lines viz., DMT2 X COHBT24 having genetic background of resistance against both ToLCV and its whitefly vector along with private sector commercial hybrids (37 Nos.) were selected. The selected populations were evaluated for resistance against ToLCV in field under natural ToLCVD incidence condition during summer season of 2017.

\section{Raising of healthy seedlings}

Tomato segregating population derived from ToLCVD resistant and tolerant parental lines along with private sector hybrids were sown in plastic pro-trays containing sterilized coir pith. The $F_{1}$ generation of segregating population was derived from the crosses between DMT2 $\mathrm{X}$ COHBT24, parents having resistance background against ToLCV were selected along with private sector hybrids. The trays were kept in insect proof glasshouse. Twentyeight days old seedlings were transplanted at 3 $\mathrm{x} 2$ feet spacing and provided irrigation and nutrients as per package of practices. The reaction of these genotypes for natural incidence of ToLCVD was recorded at monthly interval starting from 30 days after transplanting.

Severity of disease on each genotype was recorded by adopting scale developed by Muniyappa et al., (1991).

\section{Disease severity as per cent disease index (PDI)}

The observations on per cent disease index of ToLCVD of the segregating population and private sector hybrids was scored by employing the scale described by Muniyappa et al., (1991).

The observations were recorded at 30, 60 and 90 days after transplanting (DAT) and PDI was calculated as detailed below. The resistance categorization was performed based on final resistance reaction at 90 DAT. The disease progress over the study period was calculated as area under disease progress curve (AUDPC).

The disease severity was scored as described by Muniyappa et al., (1991).

The per cent disease index (PDI) was calculated by using the formula

Per cent disease index $(\mathrm{PDI})=\frac{\text { Sum of individual disease ratings }}{\text { Total number of ratings } \mathrm{XMaximum} \text { scals }} \times 100$ 
Calculation of Area under Disease Progress Curve (AUDPC) values

$A U D P C=\sum_{i=1}^{n}\left(\left\{\frac{Y i+Y(i+1)]}{2}\right\}\right) x[t(i+1)-t i]$

Where,

$Y_{i}=$ Disease severity/incidence at time $t_{i}$

$t_{(i+1)}-t_{i}=$ Time (days) between two disease severity/incidence scores

$\mathrm{n}=$ Total number of observations

\section{Results and Discussion}

The population under study (84 Nos.) comprising of segregating population from $\mathrm{F}_{1}$ generation from cross between resistant parents (47 Nos.) and private sector commercial hybrids (37 Nos.) were evaluated in field under natural ToLCVD incidence condition during summer 2017 at UAS, GKVK, Bengaluru. The results are tabulated (Table 1) and summarized (Table 2).

Among the population screened, no visual symptoms of ToLCV infection was observed in COHBTTF1/11-4, whereas maximum ToLCVD severity (48 PDI) was recorded in COHBTTF1/325-1 even at 90 days after transplanting (DAT). The total population evaluated was categorized into resistant (11 Nos.), mild infection (38 Nos.) and moderate infection (35 Nos.). The AUDPC value for ToLCVD ranged from 0 (COHBTTF1/11-4) to 1,275 (COHBTTF1/325-1).

The lines which have shown resistant reaction (11 Nos.) against ToLCV infection are COHBTTF1/11-4, COHBTTF1/99-2, COHBTTF1/132-1, COHBTTF1/86-4, COHBTTF1/99-5, COHBTTF1/220-1,
COHBTTF1/229-1, COHBTTF1/253-1, ANJU, US/404 and MAHI 701. The AUDPC values for ToLCVD of lines which have recorded resistant, mild infection and moderate infection reaction ranged from 0 to 270,90 to 780 and 405 to 1275 , respectively. Even though both the lines, COHBTTF1/89-1 and COHBTTF1/95-7 have recorded PDI values of 42 at 60 DAT, they recorded considerably less AUDPC values of 765 and 795 , respectively as against COHBTTF1/3251 , which was recorded PDI of 48 with AUDPC values of 1,275 at even date, in spite of all the above lines were categorized under moderate infection category based on PDI values at $90 \mathrm{DAT}$.

For the management of plant diseases, use of resistant varieties or hybrids is an environmentally safe approach. The identification of resistant sources and utilizing the identified resistant source(s) in further breeding programmes either by either conventional and or molecular assisted approaches is a reliable and never ending process.

The exploration of identified resistant source(s) is of highest significance for the management of diseases of crop plants, especially for the virus diseases in the context of lack of curative approaches for viral infection.

Breeding for resistance against ToLCV infection is relatively difficult task due to the fact that involvement of complex genetics of the resistance genes (Lapidot et al., 1997).

Several previous efforts could not yielded any fruitful results with some exceptions like development and release of tomato lines viz., TLB111, TLB130 and TLB182 for fresh fruit market from UAS Bengaluru and Arka Rakshak from IIHR Bengaluru released during 2006 with multiple disease resistance traits. 
Table.1 Evaluation of tomato segregating population and private sector hybrids for resistance to natural incidence of ToLCV under field conditions during summer 2017

\begin{tabular}{|c|c|c|c|c|c|c|}
\hline \multirow[t]{2}{*}{$\begin{array}{l}\text { Sl. } \\
\text { No. }\end{array}$} & \multirow{2}{*}{$\begin{array}{l}\text { Segregating } \\
\text { population/Private } \\
\text { sector hybrids }\end{array}$} & \multicolumn{3}{|c|}{$\begin{array}{c}\text { PDI at days after } \\
\text { transplanting (DAT) }\end{array}$} & \multirow[t]{2}{*}{ AUDPC } & \multirow[t]{2}{*}{ Resistance category } \\
\hline & & 30 & 60 & 90 & & \\
\hline 1 & COHBTTF1/11-4 & 0.00 & 0.00 & 0.00 & 0.00 & Resistant \\
\hline 2 & COHBTTF1/11-5 & 8.00 & 10.00 & 22.00 & 495.00 & Mild infection \\
\hline 3 & COHBTTF1/13-4 & 12.00 & 18.00 & 28.00 & 750.00 & Mild infection \\
\hline 4 & COHBTTF1/28-5 & 4.00 & 14.00 & 24.00 & 480.00 & Mild infection \\
\hline 5 & COHBTTF1/31-2 & 16.00 & 22.00 & 34.00 & 945.00 & Moderate infection \\
\hline 6 & COHBTTF1/31-5 & 6.00 & 16.00 & 24.00 & 555.00 & Mild infection \\
\hline 7 & COHBTTF1/33-4 & 10.00 & 20.00 & 46.00 & 870.00 & Moderate infection \\
\hline 8 & COHBTTF1/37-5 & 12.00 & 22.00 & 44.00 & 930.00 & Moderate infection \\
\hline 9 & COHBTTF1/79-4 & 4.00 & 10.00 & 18.00 & 375.00 & Mild infection \\
\hline 10 & COHBTTF1/80-1 & 0.00 & 12.00 & 16.00 & 300.00 & Mild infection \\
\hline 11 & COHBTTF1/80-2 & 4.00 & 14.00 & 20.00 & 450.00 & Mild infection \\
\hline 12 & COHBTTF1/83-1 & 2.00 & 8.00 & 12.00 & 255.00 & Mild infection \\
\hline 13 & COHBTTF1/86-4 & 0.00 & 2.00 & 2.00 & 45.00 & Resistant \\
\hline 14 & COHBTTF1/86-5 & 12.00 & 28.00 & 40.00 & 990.00 & Moderate infection \\
\hline 15 & COHBTTF1/89-1 & 8.00 & 18.00 & 42.00 & 765.00 & Moderate infection \\
\hline 16 & COHBTTF1/89-2 & 8.00 & 20.00 & 32.00 & 720.00 & Moderate infection \\
\hline 17 & COHBTTF1/89-3 & 2.00 & 18.00 & 32.00 & 555.00 & Moderate infection \\
\hline 18 & COHBTTF1/89-5 & 8.00 & 26.00 & 36.00 & 840.00 & Moderate infection \\
\hline 19 & COHBTTF1/91-1 & 0.00 & 22.00 & 36.00 & 600.00 & Moderate infection \\
\hline 20 & COHBTTF1/91-5 & 2.00 & 18.00 & 38.00 & 600.00 & Moderate infection \\
\hline 21 & COHBTTF1/91-6 & 8.00 & 18.00 & 34.00 & 705.00 & Moderate infection \\
\hline 22 & COHBTTF1/95-6 & 4.00 & 16.00 & 38.00 & 615.00 & Moderate infection \\
\hline 23 & COHBTTF1/95-7 & 8.00 & 20.00 & 42.00 & 795.00 & Moderate infection \\
\hline 24 & COHBTTF1/99-2 & 0.00 & 2.00 & 2.00 & 45.00 & Resistant \\
\hline 25 & COHBTTF1/99-5 & 0.00 & 2.00 & 2.00 & 45.00 & Resistant \\
\hline 26 & COHBTTF1/132-1 & 0.00 & 0.00 & 4.00 & 30.00 & Resistant \\
\hline 27 & COHBTTF1/137-5 & 0.00 & 10.00 & 14.00 & 255.00 & Mild infection \\
\hline 28 & COHBTTF1/218-1-1 & 6.00 & 16.00 & 22.00 & 540.00 & Mild infection \\
\hline 29 & COHBTTF1/218-2 & 0.00 & 4.00 & 16.00 & 180.00 & Mild infection \\
\hline 30 & COHBTTF1/218-3 & 0.00 & 8.00 & 12.00 & 210.00 & Mild infection \\
\hline 31 & COHBTTF1/220-1 & 2.00 & 4.00 & 6.00 & 150.00 & Resistant \\
\hline 32 & COHBTTF1/228-2 & 6.00 & 8.00 & 10.00 & 330.00 & Mild infection \\
\hline 33 & COHBTTF1/228-6 & 6.00 & 10.00 & 14.00 & 390.00 & Mild infection \\
\hline 34 & COHBTTF1/229-1 & 2.00 & 6.00 & 8.00 & 195.00 & Resistant \\
\hline 35 & COHBTTF1/245-1 & 6.00 & 10.00 & 14.00 & 390.00 & Mild infection \\
\hline 36 & COHBTTF1/253-1 & 0.00 & 0.00 & 4.00 & 30.00 & Resistant \\
\hline 37 & COHBTTF1/270-1 & 12.00 & 22.00 & 40.00 & 900.00 & Moderate infection \\
\hline 38 & COHBTTF1/270-2 & 6.00 & 8.00 & 12.00 & 345.00 & Mild infection \\
\hline 39 & COHBTTF1/270-5 & 14.00 & 28.00 & 42.00 & 1050.00 & Moderate infection \\
\hline 40 & COHBTTF1/283-1 & 0.00 & 8.00 & 26.00 & 315.00 & Mild infection \\
\hline
\end{tabular}


Int.J.Curr.Microbiol.App.Sci (2019) 8(8): 844-852

\begin{tabular}{|c|c|c|c|c|c|c|}
\hline 41 & COHBTTF1/283-2 & 14.00 & 32.00 & 46.00 & 1140.00 & Moderate infection \\
\hline 42 & COHBTTF1/325-1 & 18.00 & 34.00 & 48.00 & 1275.00 & Moderate infection \\
\hline 43 & COHBTTF1/325-3 & 12.00 & 24.00 & 40.00 & 930.00 & Moderate infection \\
\hline 44 & COHBTTF1/325-4 & 16.00 & 32.00 & 42.00 & 1155.00 & Moderate infection \\
\hline 45 & COHBTTF1/330-1 & 8.00 & 18.00 & 32.00 & 690.00 & Moderate infection \\
\hline 46 & COHBTTF1/330-8 & 12.00 & 30.00 & 44.00 & 1050.00 & Moderate infection \\
\hline 47 & COHBTTF1/349-3 & 10.00 & 24.00 & 42.00 & 900.00 & Moderate infection \\
\hline 48 & US/4545 & 0.00 & 0.00 & 12.00 & 90.00 & Mild infection \\
\hline 49 & US/809 & 0.00 & 8.00 & 10.00 & 195.00 & Mild infection \\
\hline 50 & US/2853 & 0.00 & 4.00 & 10.00 & 135.00 & Mild infection \\
\hline 51 & US/3383 & 4.00 & 24.00 & 32.00 & 690.00 & Moderate infection \\
\hline 52 & US/04 & 6.00 & 8.00 & 10.00 & 330.00 & Mild infection \\
\hline 53 & US/3330 & 4.00 & 16.00 & 22.00 & 495.00 & Mild infection \\
\hline 54 & US/404 & 6.00 & 6.00 & 6.00 & 270.00 & Resistant \\
\hline 55 & NS/592 & 0.00 & 0.00 & 16.00 & 120.00 & Mild infection \\
\hline 56 & NS/524 & 2.00 & 12.00 & 34.00 & 480.00 & Moderate infection \\
\hline 57 & NS/505 & 0.00 & 20.00 & 32.00 & 540.00 & Moderate infection \\
\hline 58 & $\mathrm{NS} / 526$ & 8.00 & 16.00 & 22.00 & 585.00 & Mild infection \\
\hline 59 & NAINA & 6.00 & 26.00 & 42.00 & 840.00 & Moderate infection \\
\hline 60 & ABHILASH & 0.00 & 8.00 & 26.00 & 315.00 & Mild infection \\
\hline 61 & TRISHUL & 0.00 & 8.00 & 38.00 & 405.00 & Moderate infection \\
\hline 62 & ARUNA & 0.00 & 0.00 & 16.00 & 120.00 & Mild infection \\
\hline 63 & ALANKAR & 0.00 & 16.00 & 30.00 & 465.00 & Moderate infection \\
\hline 64 & LAKSHMI & 4.00 & 10.00 & 32.00 & 480.00 & Moderate infection \\
\hline 65 & AVISHKAR & 14.00 & 18.00 & 22.00 & 750.00 & Mild infection \\
\hline 66 & SAMPOORNA & 8.00 & 12.00 & 12.00 & 450.00 & Mild infection \\
\hline 67 & SHAHENSHA & 10.00 & 12.00 & 26.00 & 600.00 & Mild infection \\
\hline 68 & APOORVA & 6.00 & 20.00 & 32.00 & 675.00 & Moderate infection \\
\hline 69 & GARVA & 0.00 & 10.00 & 12.00 & 240.00 & Mild infection \\
\hline 70 & ANJU & 4.00 & 6.00 & 6.00 & 225.00 & Resistant \\
\hline 71 & CHIRAYU & 4.00 & 10.00 & 36.00 & 510.00 & Moderate infection \\
\hline 72 & SATYAM & 6.00 & 18.00 & 22.00 & 570.00 & Mild infection \\
\hline 73 & RASSAM & 0.00 & 18.00 & 20.00 & 420.00 & Mild infection \\
\hline 74 & HYB 3252 & 12.00 & 28.00 & 36.00 & 960.00 & Moderate infection \\
\hline 75 & INDUS 1030 & 2.00 & 16.00 & 28.00 & 495.00 & Mild infection \\
\hline 76 & INDAM 535 & 0.00 & 6.00 & 22.00 & 255.00 & Mild infection \\
\hline 77 & INDAM 1004 & 12.00 & 22.00 & 24.00 & 780.00 & Mild infection \\
\hline 78 & NIRUPAM & 12.00 & 24.00 & 36.00 & 900.00 & Moderate infection \\
\hline 79 & JKTH 811 & 12.00 & 18.00 & 40.00 & 840.00 & Moderate infection \\
\hline 80 & MAHI 701 & 0.00 & 4.00 & 6.00 & 105.00 & Resistant \\
\hline 81 & NOVO81 & 2.00 & 24.00 & 28.00 & 615.00 & Mild infection \\
\hline 82 & HEEM SHIKHAR & 12.00 & 24.00 & 30.00 & 855.00 & Moderate infection \\
\hline 83 & CHANDINI & 8.00 & 18.00 & 28.00 & 660.00 & Mild infection \\
\hline 84 & SUPER GANESHA & 0.00 & 16.00 & 20.00 & 390.00 & Mild infection \\
\hline
\end{tabular}

DAT- Days After Transplanting

AUDPC- Area Under Disease Progress Curve 
Table.2 Summary of evaluation of tomato segregating population and private sector hybrids based on resistance to natural incidence of ToLCV screened under field condition during summer 2017

\begin{tabular}{|c|c|c|c|c|c|c|}
\hline $\begin{array}{l}\text { Sl. } \\
\text { No. }\end{array}$ & $\begin{array}{l}\text { Resistance } \\
\text { category } \\
\text { (AUDPC) }\end{array}$ & $\begin{array}{l}\text { Total } \\
\text { number }\end{array}$ & \multicolumn{4}{|c|}{ Segregating population / Private sector hybrids } \\
\hline 1 & $\begin{array}{l}\text { Resistant } \\
(0-270)\end{array}$ & 11 & \multicolumn{2}{|l|}{$\begin{array}{l}\text { COHBTTF1/11-4 } \\
\text { COHBTTF1/99-2 } \\
\text { COHBTTF1/132-1 } \\
\text { COHBTTF1/229-1 }\end{array}$} & \multicolumn{2}{|c|}{$\begin{array}{l}\text { COHBTTF1/86-4 } \\
\text { COHBTTF1/99-5 } \\
\text { COHBTTF1/220-1 } \\
\text { COHBTTF1/253-1 } \\
\text { MAHI 701 }\end{array}$} \\
\hline 2 & $\begin{array}{l}\text { Mild infection } \\
(90-780)\end{array}$ & 38 & $\begin{array}{l}\text { COHBTTF1/11-5 } \\
\text { COHBTTF1/28-5 } \\
\text { COHBTTF1/79-4 } \\
\text { COHBTTF1/80-2 } \\
\text { COHBTTF1/137-5 } \\
\text { COHBTTF1/218-2 } \\
\text { COHBTTF1/228-2 } \\
\text { COHBTTF1/245-1 } \\
\text { COHBTTF1/283-1 } \\
\text { US/04 } \\
\text { US/3330 } \\
\text { NS/592 } \\
\text { INDAM 535 } \\
\text { INDUS 1030 } \\
\text { SUPER GANESHA } \\
\text { SHAHENSHA }\end{array}$ & $\begin{array}{l}\text { US/8 } \\
\text { US/4 } \\
\text { ARU } \\
\text { INDA } \\
\text { ABH } \\
\text { NOV } \\
\text { CHAl }\end{array}$ & $\begin{array}{l}\mathrm{COHB} \\
\mathrm{COHB} \\
\mathrm{COHB} \\
\mathrm{COHB} \\
\mathrm{COHB} \\
\mathrm{COHB} \\
\mathrm{COHB} \\
\mathrm{COHB}\end{array}$ & $\begin{array}{l}\text { 3TTF1/13-4 } \\
\text { 3TTF1/31-5 } \\
\text { 3TTF1/80-1 } \\
\text { 3TTF1/83-1 } \\
\text { 3TTF1/218-1-1 } \\
\text { 3TTF1/218-3 } \\
\text { 3TTF1/228-6 } \\
\text { 3TTF1/270-2 } \\
\\
\text { US/2853 } \\
\text { NS/526 } \\
\text { GARVA } \\
\text { 4 RASSAM } \\
\text { SATYAM } \\
\text { SAMPOORNA } \\
\text { AVISHKAR }\end{array}$ \\
\hline 3 & $\begin{array}{l}\text { Moderate } \\
\text { infection } \\
(405-1275)\end{array}$ & 35 & $\begin{array}{l}\text { COHBTTF1/31-2 } \\
\text { COHBTTF1/37-5 } \\
\text { COHBTTF1/89-1 } \\
\text { COHBTTF1/89-3 } \\
\text { COHBTTF1/91-1 } \\
\text { COHBTTF1/91-6 } \\
\text { COHBTTF1/95-7 } \\
\text { COHBTTF1/270-5 } \\
\text { COHBTTF1/325-1 } \\
\text { COHBTTF1/325-4 } \\
\text { 1COHBTTF1/330-8 } \\
\text { TRISHUL ALANI } \\
\text { NS/524 LAKSF } \\
\text { APOORVA US/338 } \\
\text { JK 811 HYB 3252 } \\
\text { NIRUPAM }\end{array}$ & $\begin{array}{l} \\
\text { KAR } \\
\text { KMI } \\
3 \\
\end{array}$ & $\begin{array}{l}\text { COHB } \\
\text { COHB } \\
\text { COHB } \\
\text { COHB } \\
\text { COHB } \\
\text { COHB } \\
\text { COHB } \\
\text { COHB } \\
\text { COHB } \\
\text { COHB } \\
\text { COHB } \\
\end{array}$ & $\begin{array}{l}\text { 3TTF1/33-4 } \\
\text { 3TTF1/86-5 } \\
\text { 3TTF1/89-2 } \\
\text { 3TTF1/89-5 } \\
\text { 3TTF1/91-5 } \\
\text { 3TTF1/95-6 } \\
\text { 3TTF1/270-1 } \\
\text { 3TTF1/283-2 } \\
\text { 3TTF1/325-3 } \\
\text { 3TTF1/330- } \\
\text { 3TTF1/349-3 } \\
\text { NS/505 } \\
\text { CHIRAYU } \\
\text { NAINA SHIKHAR }\end{array}$ \\
\hline 4 & Susceptible & - & - & & & \\
\hline
\end{tabular}




\section{Disease severity as per cent disease index (PDI)}

\begin{tabular}{|c|c|c|c|}
\hline & Category & & Description \\
\hline $\mathbf{1}$ & Resistance (R) & $=$ & No symptoms \\
\hline $\mathbf{2}$ & Mild infection (M) & $=$ & $\begin{array}{c}\text { Light yellowing along margins but no curling of } \\
\text { leaves. Only few plants were infected. }\end{array}$ \\
\hline $\mathbf{3}$ & Moderate infection (Mo) & $=$ & $\begin{array}{c}\text { Light yellowing along margin, slight curling and } \\
\text { stunting }\end{array}$ \\
\hline $\mathbf{4}$ & Susceptible (S) & $=$ & $\begin{array}{c}\text { Very severe curling of leaves, stunting of plants and } \\
\text { significant yield loss. }\end{array}$ \\
\hline
\end{tabular}

In spite of the challenges, breeding for disease resistance is being explored for its potentials like safety to environment besides reducing the cost involved for plant protection. In the present study, the successful management of ToLCVD by breeding lines which have shown considerable resistance to ToLCV infection like DMT2 X COHBT24 were used as parents to develop the $F_{1}$ hybrids and the segregating population from $F_{1}$ generation along with the selected commercially available private sector hybrids. For rigorous screening of the lines/hybrids available, field screening method based on visual observations under natural incidence or some times by deploying both in vitro and field evaluation methods and comparing the same were deployed for reliable results. Many earlier workers followed the crossing of ToLCV resistant parents of tomato to develop either resistant $\mathrm{F}_{1}$ 's or lines (Singh, 2014; Ray et al., 2017).

The present study was performed in field under natural incidence condition. The segregating population viz., COHBTTF1/114, COHBTTF1/86-4, COHBTTF1/99-2, COHBTTF1/99-5, COHBTTF1/132-1, COHBTTF1/220-1, COHBTTF1/229-1, COHBTTF1/253-1, ANJU, US/404 and MAHI 701 have exhibited resistant reaction consistently against ToLCVD. Hence, theses can be either directly used for commercial cultivation or for further breeding programme after assessing desirable horticultural traits.
In field evaluation studies, lines COHBTTF1/89-1 and COHBTTF1/95-7 under moderate infection category recorded less progression of disease in comparison to other lines by taking infection late as compared to other lines in the respective resistance category.

It has been reported that the extent of yield loss due to ToLCV infection under field condition is directly proportional to earliness of initiation of virus infection (Saikia and Muniyappa, 1989). More specifically, up to 45 days after transplanting (DAT) is more critical time for infection of ToLCV in relation to its effect of ToLCVD on yield (Sajeed Ali et al., 2002).

Avinash-2 and US-1008 have been recorded as moderately resistant based on visual scoring (Singh, 2014).

The delay in initiation of infection of ToLCV under field condition will considerably reduce the final impact of the disease on reduction in fruit yield.

Hence, the rate of progress of disease as inferred by AUDPC values will be additional significant criteria which needs to be considered along with quantifying the disease at particular stage of the crop growth either as Per cent Incidence (PI) or Per cent Disease Index (PDI) for resistance categorization of tomato varieties / hybrids against ToLCVD. 


\section{References}

Anonymous, 2013. National Horticulture Mission, 3rd January to 12th January, pp10.

Anonymous, 2017. Horticulture statistics at a glance 2017. Pp74.

Brown, J. K. 2010. Bemisia: Bionomics and Management of a Global Pest. (P. A. Stansly \& S. E. Naranjo, Eds.). Dordrecht: Springer Netherlands. 4: 211-234.

Brown, J. K., Fauquet, C. M., Briddon, R. W., Zerbini, M., Moriones, E. and NavasCastillo, J. 2011. Family Geminiviridae. In: Virus Taxonomy. Ninth Report of the International Committee on Taxonomy of Viruses, $1^{\text {st }}$ ed. Amsterdam: ElsevierAcademic. p. 351-373.

Lapidot, M., Friedmann, M., Lachman, O., Yehezkwel, A., Nahon, S., Cohen, S. and Pilowsky, M. 1997. Comparison of resistance level to Tomato yellow leaf curl virus among commercial cultivars and breeding lines. Pl. Dis., 81: 14251428.

Muniyappa, V., Jalikoppa, S. H., Saikia, A. K., Channarayappa, Shivashankar, G., Ishwarbhat, A. and Ramappa, H. K.
1991. Reaction of Lycopersicon sp. and wild accessions to Tomato leaf curl virus. Euphytica, 56: 37-41.

Muniyappa, V., Padmaja, A. S., Venkatesh, H. M., Sharma, A. and Chandrashekar, S. 2002. Tomato leaf curl virus resistant tomato lines TLB111, TLB 130 and TLB182. Hort. Sci., 37(3): 603-606.

Ray, P. K., Verma, R. B., Solankey, S. S. and Chaudhary, A. 2017. Screening of tomato genotypes for Tomato leaf curl virus resistance. Int. J. Chemc. Studies, 5(6): 1703-1706.

Saikia, A. K. And Muniyappa, V. 1989. Epidemiology and control of Tomato leaf curl virus in Southern India. Trop. Agril., 66: 350-354.

Sajeed Ali, De, B. K., Nath, P.S., Yadav, V. B., Wangchu, L. and Ali, S. 2002. Tomato leaf curl virus disease on different tomato cultivars in the New Alluvial Zone of West Bengal. Env. Ecol., 20: 908-911.

Singh, K. 2014. Evaluation of tomato genotypes and its reaction against ToLCV causing leaf curl disease in tomato (Solanum lycopersicon L.). J. Expertal. Biol. Agril. Sci, 2(1S): 120125.

\section{How to cite this article:}

Raghavendra Achari, B. Fakruddin, K.T. Rangaswamy, D.L. Savithramma, Kedarnath, N. Nagaraju and Prameela, H.A. 2019. Screening for Identification of Resistance Sources of Tomato against Tomato Leaf Curl Virus (ToLCV) from Segregating Population and Private Sector Hybrids under Natural Disease Incidence. Int.J.Curr.Microbiol.App.Sci. 8(08): 844-852. doi: https://doi.org/10.20546/ijcmas.2019.808.097 